\title{
Exigência de Metionina Mais Cistina para Codornas Japonesas em Postura ${ }^{1}$
}

\section{Rogério Pinto 2 , Juarez Lopes Donzele ${ }^{3}$, Aloízio Soares Ferreira ${ }^{3}$, Luiz Fernando Teixeira Albino ${ }^{3}$, Rita da Trindade Ribeiro Nobre Soares ${ }^{4}$, Martinho de Almeida e Silva ${ }^{5}$, Thais Alves Pereira ${ }^{6}$}

\footnotetext{
RESUMO - Foram utilizadas 360 codornas fêmeas, com idade inicial de 45 dias e peso médio de 137,0 g, durante quatro períodos de 28 dias. O delineamento experimental foi em blocos ao acaso, com seis relações metionina mais cistina digestível: lisina digestível $(0,60$, $0,65,0,70,0,75,0,80$ e 0,85$)$ e seis repetições de 10 animais cada. As variáveis estudadas foram: postura (\%), peso do ovo (g), massa de ovos (g de ovos/codorna/dia), consumo alimentar (g), conversão alimentar (g de ração/g de ovos e g de ração/dz de ovos), peso final (g) e porcentagem da casca do ovo (\%). Os tratamentos experimentais não influenciaram a conversão alimentar e o peso final das codornas, apresentando efeito quadrático sobre a taxa de postura, peso dos ovos, massa dos ovos e porcentagem da casca dos ovos e efeito linear para o consumo alimentar. A exigência em metionina mais cistina digestível foi estimada em $0,727 \%$, para consumo diário de $164 \mathrm{mg}$ de metionina mais cistina digestível, e a melhor relação metionina mais cistina digestível: lisina digestível para as codornas japonesas em postura foi estimada em 0,80 .
}

Palavras-chave: aminoácidos sulfurosos, Coturnix coturnix japonica, digestibilidade, produção de ovos, proteína ideal

\section{Methionine Plus Cystine Requirement for Laying Japanese Quails}

\begin{abstract}
Three hundred and sixty 45-days old female quails, averaging $137.0 \mathrm{~g}$, were used during four experimental periods of 28 days each. A completely randomized block design, with six replicates and ten females per experimental unit, was used to study the digestible methionine plus cystine requirement and the best digestible methionine plus cystine: digestible lysine ratio $(0.60,0.65$, $0.70,0.75,0.80$ and 0.85$)$, on the rate of eggs production (\%), egg weight (g), eggs mass (g of eggs/quail/day), feed intake (g), feed consumption: weight gain ratio ( $\mathrm{g}$ of diet/g of eggs), body weight $(\mathrm{g})$ and shell percentage (\%). No significant effect of treatments on feed consumption: gain diet (g of diet/g of eggs). Quadratic effects were observed for final body weight (g), egg production (\%), egg weight (g), egg mass ( $\mathrm{g}$ of eggs/quail/day) and shell egg (\%), and for feed intake ( $\mathrm{g}$ ) the effect was linear. The estimated digestible methionine plus cystine requirement was $.727 \%$, for a daily intake of $164 \mathrm{mg}$ of digestible methionine plus cystine, and the best estimated digestible methionine plus cystine: digestible lysine ratio for laying Japanese quails was .80 .
\end{abstract}

Key Words: Coturnix coturnix japonica, digestibility, egg production, ideal protein, sulfur amino acid

\section{Introdução}

No Brasil, uma das atividades que mais tem se desenvolvido é a coturnicultura, criação de codornas japonesas (Coturnix coturnix japonica), despertando a atenção e o interesse de pesquisadores da área avícola no sentido de desenvolver trabalhos que venham contribuir para maior aprimoramento e fixação desta exploração como fonte rentável na produção avícola (Furlan et al., 1998).

$\mathrm{Na}$ criação de codornas, os estudos em nutrição tornam-se ainda mais importantes, pois, na formulação de rações, além dos custos elevados, são utilizadas tabelas de exigências nutricionais de outros países, como o NRC (1994), ou extrapolações dos valores nutricionais constantes nas tabelas de exigências de galinhas poedeiras ou perus, e essas informações podem não ser ideais para o desenvolvimento e desempenho adequados desta espécie em nosso país. Além disso, as dietas para codornas japonesas são formuladas com base nas exigências de proteína bruta, o que pode acarretar consumo excessivo de aminoácidos essenciais. A digestão e o metabolismo desses aminoácidos consumidos em excesso geram incremento calórico corporal desnecessário, provocando a excreção de volume excessivo de ácido úrico, com maior gasto de energia. Além disso, o excesso de aminoácidos circulantes no sangue pode

\footnotetext{
${ }^{1}$ Parte integrante da Tese de Doutorado do primeiro autor.

2 Doutor em Zootecnia pelo Programa de Pós-graduação da UFV, Rua dos Estudantes, no 25, Centro, Viçosa - MG. CEP: 3657-000. E.mail: rpinto@funec.br

${ }^{3}$ Professores - Departamento de Zootecnia, UFV - CEP: 36570-000, Viçosa - MG.

4 Professora do CCTA da Universidade Estadual do Norte Fluminense.

${ }^{5}$ Professor da Universidade Federal de Minas Gerais.

6 Zootecnista - Estagiária do Setor de Avicultura - DZO - UFV.
} 
provocar a diminuição do consumo de ração por parte dos animais (Goulart, 1997).

Os valores referentes aos níveis protéicos se destacam pois as fontes protéicas constituem-se nos componentes de maior participação no custo das rações e um dos componentes de maior importância na prática comercial devendo, portanto, estar em quantidade suficiente para suprir as necessidades das aves, sem onerar o custo de produção (Forbes \& Shariatmadari, 1994). Além disso, a proteína contida nos ingredientes da ração é um dos principais nutrientes, cuja eficiência de utilização depende da quantidade, composição e digestibilidade de seus aminoácidos, os quais são exigidos em níveis específicos pelas aves (Dale, 1994).

Graças às facilidades de compra e aos preços compatíveis, há crescente prática de se incorporar aminoácidos sintéticos nas rações, permitindo formular rações de mínimo custo com teores de PB inferiores aos recomendados nas tabelas de exigências nutricionais, porém, atendendo as exigências em aminoácidos essenciais (Silva, 1996). Com o fornecimento dos níveis aminoacídicos mais próximos das necessidades animais, há aumento na eficiência de utilização protéica e maximização do uso dos aminoácidos para síntese protéica, minimizando o seu uso como fonte de energia.

A diminuição do nível de PB da ração implica na necessidade de medidas que possam reduzir ou eliminar os problemas causados, não comprometendo o desempenho dos animais. Dessa forma, uma das possíveis soluções seria utilizar níveis de proteína bruta mais baixos, atendendo juntamente as exigências nutricionais mínimas, com a suplementação de aminoácidos na forma cristalina, maximizando a utilização das proteínas e atendendo as exigências dos animais pela manutenção dos padrões de produção obtidos em rações com níveis mais elevados de proteína bruta (Silva, 1996).

Assim, esta pesquisa procurou estimar a exigência em metionina mais cistina digestível e estabelecer a melhor relação metionina mais cistina digestível: lisina digestível para codornas japonesas em postura.

\section{Material e Métodos}

O experimento foi realizado num galpão adaptado para criação de codornas na Seção de Avicultura do Departamento de Zootecnia do Centro de Ciências Agrárias da Universidade Federal de Viçosa, no período de maio a agosto de 2001.
Foram utilizadas 360 codornas fêmeas ( Coturnix coturnix japonica), com idade inicial de 45 dias e peso médio de $137,0 \mathrm{~g}$, durante quatro períodos experimentais de 28 dias.

$\mathrm{O}$ delineamento experimental foi em blocos ao acaso, com seis relações metionina mais cistina digestível: lisina digestível $(0,60,065,0,70,0,75,0,80$ e 0,85$)$ e seis repetições, com 10 animais por unidade experimental. $\mathrm{O}$ delineamento experimental foi em blocos ao acaso, para evitar o efeito do posicionamento das gaiolas nos andares e no galpão sobre os tratamentos.

As aves foram alojadas em gaiolas de arame galvanizado, com dimensões de $1,0 \mathrm{~m}$ de comprimento $\mathrm{x} 0,25 \mathrm{~m}$ de largura $\mathrm{x} 0,20 \mathrm{~m}$ de altura, dispostas em três andares, montadas em esquema de escada, sem bandeja coletora de fezes sob as gaiolas. Cada gaiola foi subdividida em duas repartições iguais de $0,50 \mathrm{~m}$. Sobre o piso de cimento, logo abaixo das gaiolas, foi colocada uma camada de pó de madeira, para absorção da umidade das fezes. O comedouro e o bebedouro utilizados foram do tipo calha, em chapa metálica galvanizada, ambos percorrendo a extensão das gaiolas, sendo o comedouro na parte frontal e o bebedouro na parte posterior da gaiola.

Os animais foram submetidos à ração basal (Tabela 1), deficiente em metionina mais cistina, formulada a base de milho e farelo de soja, contendo $19,29 \%$ de proteína bruta (PB), $2.900 \mathrm{kcal}$ de EM/ $\mathrm{kg}$ de ração, $0,910 \%$ de lisina digestível e $0,550 \%$ de metionina mais cistina digestível, correspondendo à relação de metionina mais cistina digestível: lisina digestível de 0,60 .

A ração basal foi suplementada com cinco níveis de DL- metionina (99\%), em substituição ao amido de milho, correspondendo aos níveis de 0,550 (ração basal sem suplementação), 0,592, 0,637, 0,683, 0,728 e $0,774 \%$ de metionina mais cistina digestível, permanecendo as rações isocalóricas. As rações foram formuladas com base no conteúdo aminoacídico digestível verdadeiro dos alimentos, determinados pelo método de alimentação precisa de Sibbald, utilizando galos cecectomizados, apresentado em Rostagno et al. (2000) e as exigências nutricionais das codornas japonesas em crescimento, constantes no NRC (1994), exceto para proteína bruta (PB), lisina e metionina mais cistina. Para todos os outros aminoácidos, as relações propostas pelo NRC (1994) foram mantidas por intermédio da suplementação de aminoácidos sintéticos em substituição ao amido de milho, em todas as rações.

R. Bras. Zootec., v.32, n.5, p.1166-1173, 2003 
Tabela 1 - Composição percentual e calculada da ração basal

Table 1 - Percentual and calculated composition of basal diet

\begin{tabular}{|c|c|c|}
\hline Ingredientes (Ingredients) & & $\%$ \\
\hline Milho (Corn) & & 58,669 \\
\hline Amido (Starch) & & 0,500 \\
\hline Farelo de soja (Soybean meal) & & 31,258 \\
\hline Fosfato bicálcico (Dicalcium phosphate) & & 1,317 \\
\hline Calcário (Limestone) & & 5,353 \\
\hline Óleo vegetal (Oil) & & 2,224 \\
\hline Sal (Salt) & & 0,280 \\
\hline Mistura mineral ${ }^{1}$ (Mineral mix) & & 0,050 \\
\hline Mistura vitamínica ${ }^{2}$ (Vitamin mix) & & 0,100 \\
\hline $\mathrm{BHT}^{3}$ & & 0,010 \\
\hline Inerte (Inert) & & 0,240 \\
\hline Total & & 100,00 \\
\hline \multicolumn{3}{|l|}{ Composição calculada (Calculated composition) } \\
\hline Proteína (Protein) $(\%)$ & & 19,290 \\
\hline EM (Metabolizable energy) ( $\mathrm{kcal} / \mathrm{kg})$ & & 2.900 \\
\hline Cálcio (Calcium) $(\%)$ & & 2,500 \\
\hline Fósforo disponível (Available phosphorus) (\%) & & 0,350 \\
\hline Sódio (Sodium) $(\%)$ & & 0,150 \\
\hline Aminoácidos (Amino acids) & Totais & Digestíveis $^{4}$ (Digestible) \\
\hline$\overline{\text { Lisina (Lysine) (\%) }}$ & 1,000 & 0,910 \\
\hline Met + Cis $(M e t+C y s)(\%)$ & 0,623 & 0,550 \\
\hline Triptofano (Tryptophan) (\%) & 0,238 & 0,215 \\
\hline Treonina (Threonine) $(\%)$ & 0,750 & 0,652 \\
\hline Metionina (Methionine) $(\%)$ & 0,312 & 0,287 \\
\hline Arginina (Arginine) $(\%)$ & 1,276 & 1,196 \\
\hline Fenilalanina (Phenilalanine) $(\%)$ & 0,954 & 0,869 \\
\hline Histidina (Histidine) $(\%)$ & 0,518 & 0,480 \\
\hline Isoleucina (Isoleucine) $(\%)$ & 0,830 & 0,749 \\
\hline Valina (Valine) $(\%)$ & 0,900 & 0,797 \\
\hline
\end{tabular}

${ }^{1}$ Conteúdo/kg de mistura vitamínica (Content/kg of vitamin mix): Vit. A - 12.000.000 U.I.; Vit. $\mathrm{D}_{3}-3.600 .000$ U.I.; Vit. B $-2.500 \mathrm{mg}$; Vit B $B^{2}-8.000$ mg; Vit. B6 - 5.000 mg; Ác. pantotênico (pantothenic acid) -12.000 mg; Biotina (biotin) -200 mg; Vit. K $3-3.000$ mg; Ác. fólico (folic acid) - 1.500 mg; Ác.nicotínico (nicotinic acid) - 40.000 mg; Vit. B $12-20.000$ mcg; Selênio (seleniun) - 150 mg; Veículo, q.s.p. - 1000 g.

${ }^{2}$ Conteúdo/kg de mistura mineral (Content $/ \mathrm{kg}$ of mineral mix): Manganês (manganese) - 160,0 g; Ferro (iron) - 100,0 g; Cobre (copper) - 20,0 g; Zinco (zinc) - 100,0 g; Cobalto (cobalt) - 2,0 g; lodo (iodine) - 2,0 g; Veículo (vehicle) q.s.p. - $1000 \mathrm{~g}$.

${ }^{3}$ Antioxidante(Antioxidant).

${ }^{4}$ Conteúdo aminoacídico digestível verdadeiro, obtido por meio do método de alimentação precisa de Sibbald, utilizando galos cecectomizados, constantes em Rostagno et al. (2000)(True digestible amino acid content, obtained by means of feeding method of Sibbald, using cecectomized roosters, constant in Rostagno et al. [2000]).

Os bebedouros foram limpos periodicamente e o fornecimento de água para as codornas foi corrente.

O programa de luz utilizado foi o de 17 horas de luz, por meio de um controlador de luz do tipo "timer".

As mensurações de temperatura e umidade dentro do galpão foram registradas por meio de termômetros de máxima e mínima e de bulbo seco e bulbo úmido.

Foram analisados taxa de postura (\%), peso médio dos ovos (g), massa de ovos ( $\mathrm{g}$ de ovos/ codorna/dia), consumo de ração (g/ave/dia), conversão alimentar (g de ração/g de ovo), peso final ( $g$ ) e porcentagem da casca do ovo.

Para o controle do consumo alimentar, as rações de cada repetição dos tratamentos foram acondicio- nadas em baldes plásticos, devidamente identificados, sendo o consumo de ração medido ao término de cada período de 28 dias, por meio da diferença entre a ração fornecida e a sobra. As aves mortas e as sobras das rações foram pesadas para ajustar o controle do consumo, ganho de peso dos animais, postura e conversão alimentar ao término de cada período.

A coleta dos ovos foi feita diariamente às $17 \mathrm{~h}$ e a produção de ovos foi obtida em porcentagem ave/dia.

Para obtenção dos dados de peso médio dos ovos, foram coletados e pesados em balança de precisão de $0,01 \mathrm{~g}$ nos quatro últimos dias de cada período, os ovos de cada unidade experimental. Após a pesagem, os ovos foram quebrados e suas cascas mantidas 
identificadas para serem secas e pesadas, obtendose assim a porcentagem das cascas.

Para obtenção da massa de ovos tomou-se a produção de ovos multiplicada pelo peso médio dos ovos.

A conversão alimentar foi obtida dividindo-se o consumo médio diário de ração pela produção média de ovos em g (conversão g/g).

Os dados foram analisados utilizando-se o Programa Sistema para Análises Estatísticas e Genética - SAEG, da Universidade Federal de Viçosa (1997). A melhor relação metionina mais cistina digestível: lisina digestível e a exigência em metionina mais cistina digestível foram estimadas por meio de equações de regressão, respeitando-se a interpretação biológica das variáveis.

\section{Resultados e Discussão}

As mensurações das temperaturas máxima e mínima médias e a umidade relativa do ar dentro do galpão estão apresentadas na Tabela 2 .

A temperatura máxima verificada em todo o período experimental esta acima daquelas observadas na zona de conforto das codornas em postura (21 a $25 C^{\circ}$ ), segundo Reis (1980). Além disso, a flutuação térmica semanal verificada no galpão experimental foi de 14,0 a $30,6 \mathrm{C}^{\circ}$, ocorrendo grande variação térmica em todo período experimental. Esta alta temperatura média, acima da zona de termoneutralidade, pode ter sido responsável pela diminuição do consumo de ração pelas codornas, numa tentativa de manterem a temperatura corporal dentro de limites homeostáticos.

Na Tabela 3, são apresentados os valores médios obtidos para taxa de postura, peso do ovo, massa de ovo, consumo alimentar, conversão alimentar, peso final e porcentagem da casca do ovo para codornas japonesas em postura, alimentadas com rações de diferentes níveis de metionina mais cistina digestível.

Foi verificado efeito quadrático $(\mathrm{P}<0,01)$ dos níveis de metionina mais cistina digestível sobre a taxa de postura, de acordo com a equação $\mathrm{Y}=-90,9405+507,765 \mathrm{X}-355,871 \mathrm{X} 2\left(\mathrm{R}^{2}=0,91\right)$, Figura 1. O ponto de máxima função verificada foi de $0,713 \%$. Este nível correspondeu à relação metionina mais cistina digestível: lisina digestível de 0,78.

Estes resultados estão de acordo com os apresentados por Belo (1997), Murakami et al. (1994), Rezende (1993) e Arscott \& Pierson-Goeger (1981), que também verificaram incremento na produção dos ovos de codornas, com o aumento do nível de aminoácidos sulfurosos na ração.

O aumento dos níveis de metionina mais cistina digestível acima do limite máximo observado possivelmente causou imbalanço aminoacídico, promovendo diminuição da síntese protéica e inibição da absorção do aminoácido limitante, juntamente com o aumento do catabolismo do mesmo, como descrito por Harper et al. (1970). Isto pode ter causado redução na taxa de postura a partir do ponto de máxima função, observado em função das poedeiras terem pouca habilidade em estocar proteína, cujo metabolismo poderia estar comprometido pelo imbalaço aminoacídico.

Os níveis de metionina mais cistina digestível apresentaram efeito quadrático $(\mathrm{P}<0,01)$ sobre $\mathrm{O}$ peso dos ovos. O nível de metionina mais cistina digestível que maximizou o peso dos ovos foi de $0,739 \%$ para a relação metionina mais cistina digestível:

Tabela 2 - Temperatura e umidade relativa do ar no interior do galpão experimental

Table 2 - Temperature and air relative humidity inside the experimental shed

\begin{tabular}{lccc}
\hline $\begin{array}{l}\text { Idade das aves (dias) } \\
\text { Birds age (days) }\end{array}$ & \multicolumn{2}{c}{$\begin{array}{c}\text { Temperatura do ar }\left(\mathrm{C}^{\circ}\right) \\
\text { Air temperature }\end{array}$} & $\begin{array}{c}\text { Umidade relativa (\%) } \\
\text { Relative humidity }\end{array}$ \\
\cline { 2 - 3 } & $\begin{array}{c}\text { Máxima média } \\
\text { Maximum average }\end{array}$ & $\begin{array}{c}\text { Mínima média } \\
\text { Minimum average }\end{array}$ & \\
\hline $49-62$ & $26,25 \pm 1,75$ & $19,82 \pm 1,18$ & $47,10 \pm 1,47$ \\
$63-76$ & $24,57 \pm 1,43$ & $17,75 \pm 0,75$ & $67,83 \pm 1,15$ \\
$77-90$ & $26,43 \pm 2,57$ & $18,46 \pm 1,45$ & $75,00 \pm 1,79$ \\
$91-104$ & $28,00 \pm 2,00$ & $17,68 \pm 0,68$ & $69,96 \pm 1,75$ \\
$105-118$ & $27,50 \pm 1,90$ & $15,41 \pm 0,91$ & $69,93 \pm 3,72$ \\
$119-132$ & $28,00 \pm 1,89$ & $16,94 \pm 0,95$ & $69,92 \pm 3,72$ \\
$133-146$ & $28,50 \pm 2,10$ & $15,50 \pm 1,50$ & $70,90 \pm 5,61$ \\
$147-161$ & $27,73 \pm 2,27$ & $16,54 \pm 1,54$ & $60,46 \pm 7,16$ \\
\hline
\end{tabular}

R. Bras. Zootec., v.32, n.5, p.1166-1173, 2003 
Tabela 3 - Efeito dos níveis de metionina mais cistina digestível sobre a taxa de postura (\%), o peso do ovo (g), a massa do ovo $(\mathrm{g})$, o consumo alimentar $(\mathrm{g})$, a conversão alimentar $(\mathrm{g} / \mathrm{g})$, o peso final $(\mathrm{g})$ e a porcentagem da casca do ovo (\%) para codornas japonesas em postura

Table 3 - Effect of methionine plus cystine levels on the laying rate (\%), egg weight (g), egg mass (g), feed intake (g), feed: gain ratio $(g / g)$, final weight $(g)$, egg shell (\%) to laying Japanese quail

\begin{tabular}{|c|c|c|c|c|c|c|c|c|}
\hline $\begin{array}{l}\text { Variável } \\
\text { Variable }\end{array}$ & $\begin{array}{l}\text { Met }+ \text { cis } \\
M e t+c y s\end{array}$ & $\begin{array}{l}\text { Taxa de } \\
\text { postura } \\
\text { Laying } \\
\text { rate }\end{array}$ & $\begin{array}{l}\text { Peso } \\
\text { do ovo } \\
\text { Egg } \\
\text { weight }\end{array}$ & $\begin{array}{l}\text { Massa } \\
\text { do ovo } \\
\text { Egg } \\
\text { mass }\end{array}$ & $\begin{array}{l}\text { Consumo } \\
\text { alimentar } \\
\text { Feed } \\
\text { intake }\end{array}$ & $\begin{array}{l}\text { Conversão } \\
\text { alimentar } \\
\text { Feed: gain } \\
\text { ratio }\end{array}$ & $\begin{array}{l}\text { Peso final } \\
\text { Final } \\
\text { weight }\end{array}$ & $\begin{array}{c}\text { Casca } \\
\text { do ovo } \\
\text { Egg } \\
\text { shell }\end{array}$ \\
\hline \multicolumn{9}{|l|}{ Relação ${ }^{1}$} \\
\hline Relation & & & & & & & & \\
\hline 0,60 & 0,550 & 79,58 & 9,37 & 7,46 & 19,82 & 2,12 & 145,33 & 9,33 \\
\hline 0,65 & 0,592 & 86,78 & 9,91 & 8,60 & 20,66 & 2,08 & 146,33 & 8,73 \\
\hline 0,70 & 0,637 & 88,18 & 10,37 & 9,15 & 21,01 & 2,03 & 148,83 & 8,73 \\
\hline 0,75 & 0,683 & 89,22 & 10,57 & 9,43 & 20,95 & 1,98 & 146,50 & 8,58 \\
\hline 0,80 & 0,728 & 89,22 & 10,71 & 9,55 & 22,25 & 2,08 & 148,83 & 8,56 \\
\hline 0,85 & 0,774 & 89,50 & 10,69 & 9,58 & 22,07 & 2,06 & 146,33 & 8,65 \\
\hline $\mathrm{CV}$ & 3,84 & 2,50 & 4,85 & 4,80 & 5,34 & 3,17 & 3,47 & \\
\hline $\begin{array}{l}\text { Significância } \\
\text { Significance }\end{array}$ & & $\mathrm{P}<0,01 * *$ & $\mathrm{P}<0,01 * *$ & $\mathrm{P}<0,01 * *$ & $\mathrm{P}<0,01^{*}$ & n.s & n.s & $\mathrm{P}<0,01 * *$ \\
\hline
\end{tabular}

${ }^{1}$ Relação metionina mais cistina digestível:lisina digestível (Relation of digestible methionine plus cystine:digestible lysine) ; ${ }^{2}$ Coeficiente de Variação (Coefficient of variation)* Efeito linear pelo teste $\mathrm{F}$ (Linear effect by $\mathrm{F}$ test); ** Efeito quadrático pelo teste $\mathrm{F}$ (Quadratic effect by $\mathrm{F}$ test); n.s. - não-significativo (not significant) $(P>0,05)$.

lisina digestível de 0,81 , demonstrado pela equação: $\mathrm{Y}=-9,77564+55,4622 \mathrm{X}-37,5160 \mathrm{X}^{2}\left(\mathrm{R}^{2}=0,99\right)$, Figura 2.

Este resultado está de acordo com os apresentados por Belo (1997) e Murakami et al. (1994), que também verificaram melhora no peso dos ovos de codornas com o aumento dos níveis de aminoácidos sulfurosos nas rações. Entretanto, Stringhini et al. (1995) não verificaram melhora significativa no peso dos ovos de codornas, quando se aumentaram os níveis de aminoácidos sulfurosos das rações, embora tenha ocorrido aumento no peso dos ovos em valores absolutos. Em acordo com estes autores, Dabbert et al. (1996), trabalhando com codornas Bobwhite, não verificaram efeito dos níveis de aminoácidos sulfurosos sobre o peso de ovo.

Houve efeito quadrático $(\mathrm{P}<0,01)$ dos níveis de metionina mais cistina sobre a massa de ovo, segundo a equação $\mathrm{Y}=-25,4011+96,3883 \mathrm{X}-66,2735 \mathrm{X}^{2}$ $\left(\mathrm{R}^{2}=0,98\right)$, Figura 3. O ponto de máxima função da massa de ovos foi obtido para o nível de metionina mais cistina de $0,727 \%$, correspondendo à relação metionina mais cistina digestível: lisina digestível de 0,80 .

Entretanto, Waldroup \& Hellwig (1995) obtiveram melhora na massa de ovos, quando as rações de galinhas poedeiras à base de milho e farelo de soja eram suplementadas com níveis crescentes de aminoácidos sulfurosos.

O nível de metionina mais cistina digestível verificado para massa dos ovos esta de acordo com os observados para postura e peso dos ovos, já que esta variável é dependente daquelas outras.

Os níveis de metionina mais cistina apresentaram efeito linear $(\mathrm{P}<0,01)$ sobre o consumo de ração, segundo a equação $\mathrm{Y}=14,4479+10,1075 \mathrm{X}$ 
$\left(\mathrm{R}^{2}=0,88\right)$, Tabela 3. Resultado semelhante foi apresentado por Belo (1997), que também verificou aumento no consumo alimentar das codornas, quando o nível de aminoácidos sulfurosos nas rações aumentou. Entretanto, Arscott \& Pierson-Goeger (1981) verificaram efeito decrescente dos níveis de aminoácidos sulfurosos sobre o consumo das codornas. Já Stringuini et al. (1995), Murakami et al. (1994) e Rezende (1993), não verificaram efeito significativo dos níveis de aminoácidos sulfurosos sobre o consumo alimentar das codornas. Os resultados de consumo alimentar obtidos permitem inferir que o aumento nos níveis de metionina mais cistina digestíveis não foram suficientes para produzir imbalanço aminoacídico que resultasse na alteração do perfil plasmático do animal, ativando os mecanismos reguladores do apetite, como descrito por Harper (1970).

Sobre a conversão alimentar ( $\mathrm{g}$ de ração /g de ovo), não foi verificado efeito significativo $(\mathrm{P}>0,05)$ dos níveis de metionina mais cistina digestíveis, Tabela 3. Este resultado difere daqueles apresentados por Belo (1997) e Rezende (1993) que verificaram efeito linear decrescente dos níveis de aminoácidos sulfurosos sobre a conversão alimentar de codornas japonesas em postura. Já Murakami et al. (1994), verificaram efeito quadrático dos níveis de aminoácidos sulfurosos sobre a conversão alimentar, com o ponto

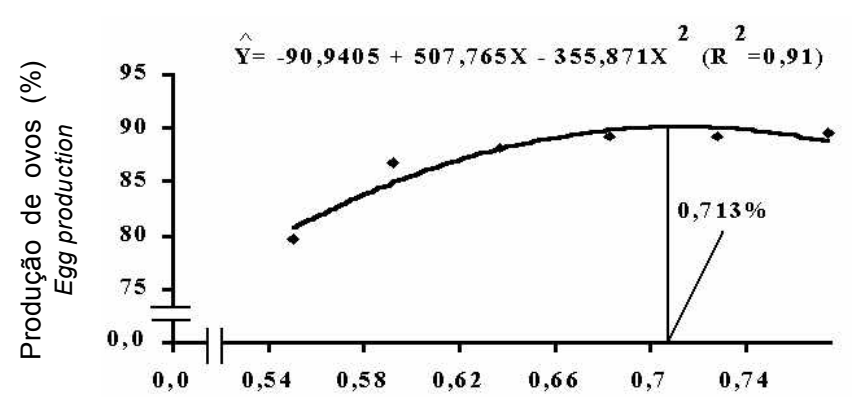

Níveis de metionina mais cistina digestível (\%) Methionine plus digestible cystine levels

Figura 1 - Efeito dos níveis de metionina mais cistina digestível sobre a produção de ovos.

Figure 1 - Effect of digestible methionine plus cystine levels on egg production. de função mínima estimada em $0,56 \%$ de metionina.

Não foi verificado efeito dos níveis de metionina mais cistina digestível para o peso final (Tabela 3). Este resultado é semelhante aos apresentados por Belo (1997) e Arscott \& Pierson-Goeger (1981), que também não verificaram efeito dos níveis de aminoácidos sulfurosos sobre o peso final das codornas em postura.

Para porcentagem da casca do ovo, verificou-se efeito quadrático $(\mathrm{P}<0,01)$, segundo a equação $\mathrm{Y}=23,5504-42,6886 \mathrm{X}+30,3255 \mathrm{X} 2(\mathrm{R} 2=0,89)$, com o ponto de função mínima de $0,704 \%$ de metionina mais cistina digestível Tabela 3 e Figura 4.

Entretanto, Belo (1997) verificou efeito linear decrescente dos níveis aminoacídicos sulfurosos sobre a porcentagem de casca dos ovos.

O efeito dos níveis de metionina mais cistina, até o ponto de função mínima, parece ter ocorrido graças à menor deposição de cálcio nas cascas dos ovos, produzindo cascas mais finas em relação ao peso dos ovos. Isso se deveu a uma produção de ovos mais intensa, já que este nível esta próximo do verificado para a máxima produção de ovos $(0,713 \%)$. O período de formação dos ovos das codornas varia de 18 a 20 horas, possibilitando a produção de dois ovos por dia, o que pode ter favorecido a diminuição da porcentagem das cascas para as codornas de maior postura e peso

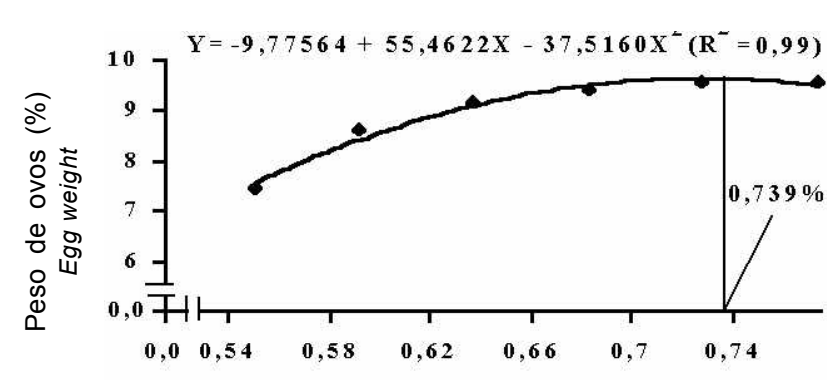

Níveis de metionina mais cistina digestível (\%) Methionine plus digestible cystine levels

Figura 2 - Efeito dos níveis de metionina mais cistina digestível sobre o peso de ovos.

Figure 2 - Effect of digestible methionine plus cystine levels on egg weight. 


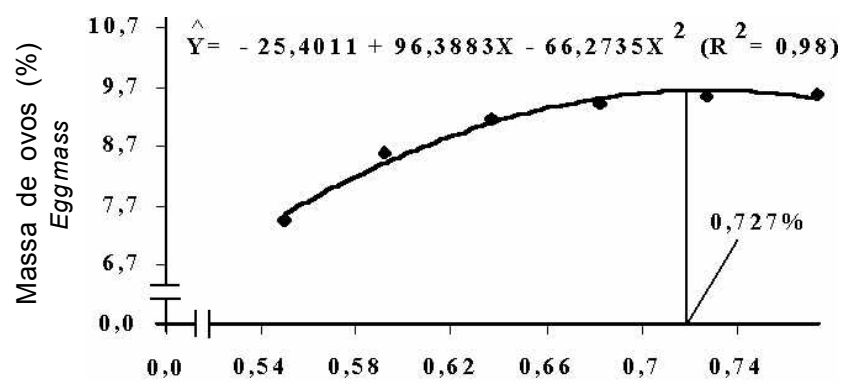

Níveis de metionina mais cistina digestível (\%) Methionine plus digestible cystine levels

Figura 3 - Efeito dos níveis de metionina mais cistina digestível sobre a massa de ovos.

Figure 3 - Effect of digestible methionine plus cystine levels on egg mass.

de ovos. Isto se tornou evidente quando foi calculado o peso das cascas dos ovos em valores absolutos, verificando-se que os ovos de menor percentagem de casca foram os que apresentaram maior peso.

A exigência em metionina mais cistina digestível para codornas japonesas em postura, baseada na relação metionina mais cistina digestível: lisina digestível, que maximiza a massa de ovos $(0,80)$ foi estimada em $0,727 \%$, correspondendo ao nível de $0,802 \%$ de metionina mais cistina total. Este valor obtido é superior aos apresentados pelo NRC (1994), Allen \& Young (1980) e Reis (1980), que, respectivamente, citam os níveis de $0,70,0,68$ e 0,65 $0,70 \%$ de metionina mais cistina total como os mais adequados para as codornas japonesas em postura. Entretanto, o valor obtido para as relações metionina mais cistina digestível neste experimento esta próximo dos apresentados por Allen \& Young (1980) e Reis (1980) para as relações metionina mais cistina: lisina totais, respectivamente, de 0,79 e 0,81 .

\section{Conclusões}

A exigência em metionina mais cistina digestível para codornas japonesas em postura foi estimada em $0,727 \%$ da ração para um consumo diário de $164,0 \mathrm{mg}$ de metionina mais cistina digestível, correspondendo à relação metionina mais cistina digestível: lisina digestível de 0,80 .

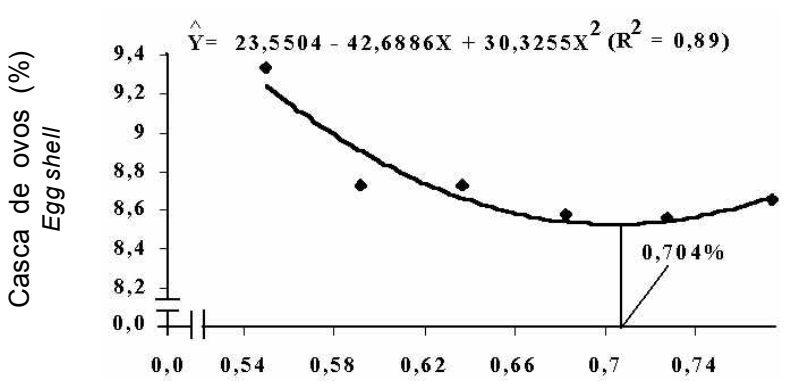

Níveis de metionina mais cistina digestível (\%) Methionine plus digestible cystine levels

Figura 4 - Efeito dos níveis de metionina mais cistina digestível sobre a porcentagem da casca dos e ovos.

Figure 4 - Effect of digestible methionine plus cystine levels on egg shell.

\section{Literatura Citada}

ALLEN, N.; YOUNG, R.J. Studies on the amino acid and protein requirements of laying Japanese quail (Coturnix coturnix japonica). Poultry Science, v.59, n.9, p.2029-2037, 1980.

ARSCOTT, G.H.; PIERSON-GOEGER, M. Protein needs for laying Japanese quail as influenced by protein level and aminoacid suplementation. Nutrition Reports International, v.24, n.6, p.1287-1295, 1981.

BELO, M.T.S. Níveis de energia metabolizável e de metionina em rações de codornas japonesas (Coturnix coturnix japonica) na fase inicial de postura. Lavras: Universidade Federal de Lavras, 1997. 80p. Dissertação (Mestrado em Nutrição de Monogástricos) - Universidade Federal de Lavras, 1997.

DABBERT, C.B.; LOCHMILLER, R.L.; WALDROUP, P.W. et al. Examination of the dietary methionine requirements of breeding northern bobwhite, colinus virginarus. Poultry Science, v.75, n.8, p.991-997, 1996.

DALE, N. Los requiremientos de nutrients: Hasta qué punto son aplicables? Avicultura Profesional, v.2, n.2, p.63-64, 1984.

FORBES, J.M.; SHARIATMANDARI, F. Diet selection for protein by poultry. World's Poultry Science Journal, v.50, n.1, p.7-23, 1994.

FURLAN, A.C.; ANDREOTTI, M.O.; MURAKAMI, A.E. et al. Valores energéticos de alguns alimentos para codornas japonesas (Coturnix coturnix japonica). Revista Brasileira de Zootecnia, v.27, n.6, p.1147, 1998.

GOULART, C.C. Exigência nutricional de lisina para poedeiras leves e semipesadas. Viçosa, MG: Universidade Federal de Viçosa, 1997. 51p. Dissertação (Mestrado em Zootecnia) Universidade Federal de Viçosa, 1997.

HARPER, A.E.; BENEVENGA, N.J.; WOHLHUETER, R.M. Effects of ingestion of disproportionate amounts of amino acids. Physiological Reviews, v.50, n.3, p.428-558, 1970.

MURAKAMI, A.E.; FURLAN, A.C.; TATEISHI, A. et al. Exigência de metionina para codornas japonesas (Coturnix coturnix 
japonica) em postura. In: REUNIÃO ANUAL DA SOCIEDADE BRASILEIRA DE ZOOTECNIA, 31., 1994, Maringá. Anáis... Maringá: Sociedade Brasileira de Zootecnia, 1994. p.64.

NATIONAL RESEARCH COUNCIL - NRC. Nutrient requirements of poultry. Washington, D.C.: National Academic Press, 1994. p.44-45.

REIS, L.F.S.D. Codornizes, criação e exploração. Lisboa, Agros, 10, 1980. 222p.

REZENDE, J.A.A. Níveis de proteína, aminoácidos sulfurosos em ração de codornas japonesas (Coturnix coturnix japonica). Rio de Janeiro: Universidade Rural do Rio de Janeiro, 1993. 39p. Dissertação (Tese Livre Docência) Universidade Rural do Rio de Janeiro, 1993.

ROSTAGNO, H.S.; ALBINO, L.F.T.; DONZELE, J.L. et al. Composição de alimentos e exigências nutricionais; (Tabelas Brasileiras). Viçosa, MG: Universidade Federal de Viçosa, 2000. 141p.

SILVA, M.A. Exigências nutricionais em metionina + cistina para frangos de corte, em função do nível de proteína bruta da ração. Viçosa, MG: Universidade Federal de Viçosa, 1996. 73p. Dissertação (Mestrado em Zootecnia) Universidade Federal de Viçosa, 1996.
STRINGHINI, J.H.; CAFÉ, M.B.; MOGYCA, N.S. et al. Níveis de energia metabolizável e metionina para codornas japonesas em postura (Coturnix coturnix japonica) In: CONFERÊNCIA APINCO DE CIÊNCIA E TECNOLOGIA AVÍCOLA, 1995, Campinas. Anais... Campinas: FACTA, 1995. p.125-126.

SCHUTTE, J.B.; JONG, J.; BERTRAM, H.L. Requirement of the laying hen for sulfur amino acids. Poultry Science, v.73, n.2, p.274-280, 1994.

UNIVERSIDADE FEEDERAL DE VIÇOSA - UFV. SAEG Sistema para análise estatística e genética. Versão 8.0. Viçosa, MG: Fundação Arthur Bernardes, 1999.

WALDROUP, P.W.; HELLWIG, H.M. Methionine and total sulfur amino acid requirements influenced by stage of production. Journal of Applied Poultry Science, v.4, n.2, p.283-292, 1995.

Recebido em: $12 / 08 / 02$

Aceito em: 13/11/02 